\title{
HEYL wt Allele
}

National Cancer Institute

\section{Source}

National Cancer Institute. HEYL wt Allele. NCI Thesaurus. Code C114521.

Human HEYL wild-type allele is located in the vicinity of 1 p34.3 and is approximately $17 \mathrm{~kb}$ in length. This allele, which encodes hairy/enhancer-of-split related with YRPW motif-like protein, is involved in the modulation of both cardiac development and transcriptional regulation. 